FINAL VERSION: Carrero-Pazos, M., Vilas-Estévez, B., Vázquez-Martínez, A. 2018. Digital imaging techniques for recording and analysing prehistoric rock art panels in Galicia (NW Iberia). Digital Applications in Archaeology and Cultural Heritage 8, 35-45.

https://doi.org/10.1016/i.daach.2017.11.003

\title{
DIGITAL IMAGING TECHNIQUES FOR RECORDING AND ANALYSING PREHISTORIC ROCK ART PANELS IN GALICIA (NW IBERIA)
}

\author{
Miguel Carrero-Pazos \\ University of Santiago de Compostela \\ miguel.carrero.pazos@gmail.com \\ Benito Vilas-Estévez \\ University of Vigo \\ benito.arborearqueoloxia@gmail.com \\ Alia Vázquez-Martínez \\ University of Santiago de Compostela \\ alia.vazquez.mtnez@gmail.com
}

\begin{abstract}
Several works have highlighted the relevance of 3D modelling techniques for the study of rock art, especially in case of deteriorated state of preservation. This paper presents a methodological approach to accurate document two Bronze Age rock art panels in Galicia (Spain), using photogrammetry SfM. The main aim is to show the application of digital enhancement techniques which have allowed the accurate depiction of the motifs and the correction of previous calques, focusing on the application of the exaggerated shading as a novel analytical method.
\end{abstract}

Keywords: Digital rock art recording; 3D modelling; Photogrammetry; Radiance Scaling; Xshade; Petroglyphs; Rock Art Carving.

\section{INTRODUCTION AND RELATED WORK}

3D modelling techniques are nowadays a standard methodology to study rock art, aiming further accuracy in the documentation process compared to traditional methodologies such as handmade tracings (Ortiz Sanz et al. 2010; Scopigno et al. 2011; Domingo et al. 2013).

From this perspective, different works have been focusing on the development of digital techniques to implement a better visualization of the 3D archaeological models (see Robin, 2015 -for a synthesis-). The application of the Polynomial Texture Mapping (PMT) (Malzbender et al. 2000, 2001) or the Reflection Transformation Imaging (RTI) (Malzbender et al. 2006) have jointly generated an advanced level of interaction with the 3D models, enhancing their topographic surface (Earl et al. 2010; Díaz-Guardamino et al. 2015). 
FINAL VERSION: Carrero-Pazos, M., Vilas-Estévez, B., Vázquez-Martínez, A. 2018. Digital imaging techniques for recording and analysing prehistoric rock art panels in Galicia (NW Iberia). Digital Applications in Archaeology and Cultural Heritage 8, 35-45.

https://doi.org/10.1016/j.daach.2017.11.003

Concerning rock art studies, it is well known that traditional techniques such as "frottage", wax and latex rubbing are insufficient to document endangered rock art panels in a detailed and non-intrusive way (Simpson et al. 2004; Cassen and Robin 2010; Plets et al. 2012, 139). Both image based modelling -dense photogrammetry- (ElHakim et al. 2004; Chandler et al. 2005), and range-based methods (Robson et al. 2001; Escarcena et al. 2011) are typically-used approaches to fill this gap (Díaz-Andreu et al. 2006; Lerma et al. 2010; Plets et al. 2012), jointly with RTI techniques (Pitts et al. 2014a,b).

Concerning the enhancement of the morphological features of 3D rock art models, several contributions have proliferated (see i. e. Vicent et al. 1996; Montero et al. 1998; Mudge et al. 2006, 2012; Díaz-Guardamino and Wheatley 2013; Olsen and Bryant 2013; Duffy 2013; Domingo et al. 2013; Grimaud 2015; Pires et al. 2015; Robin, 2015 for a synthetic view-), being the MeshLab shader Radiance Scaling (Vergne et al. 2010; Granier et al. 2012) one of the latest utilised (Medici and Rossi 2015; Vilas Estévez et al. 2017). The application of LiDAR visualisation techniques commonly used in landscape archaeological works for structure detection is also being conducted upon rock art panels (Lymer 2015; Carrero-Pazos et al. 2016).

In Galicia (NW of Iberian Peninsula), 3D modelling techniques have been recently implemented, looking for the achievement of a 3D model through range and passive sensors. Different works have been focusing on this aim through the use of laser scanner and also with photogrammetric techniques (Mañana Borrazás et al. 2009; Ortiz Sanz et al. 2010; Martínez Rodríguez et al. 2012; Gil Docampo et al. 2011). From here, digital image techniques were used to depict the details of the rock surfaces, for instance with Radiance Scaling (Vilas Estévez et al. 2017). A method that has to be noted is the Morphological Residual Model (MRM), a deviation-map methodology developed by $\mathrm{H}$. Pires which allows a better visualization of the microsurface details of the 3D models (Caninas et al. 2011; Pires et al. 2014; Correia Santos et al. 2014; Correia Santos et al. 2015; Pires et al. 2015).

In this work, a research centred on the creation of 3D models to document two rock art panels is presented, using the commercial computer vision-based package Agisoft Photoscan. This has allowed the creation of scaled models through photogrammetry Structure from Motion. Once the 3D model was created, two methods were used to preliminary study the motifs of the rock: virtual lights and the MeshLab shader Radiance Scaling. The results were compared with the application of the exaggerated shading technique, created by S. Rusinkiewicz (et al. 2006) and available through Xshade open source software ${ }^{1}$, which is based on dynamically adjusting the effective light position for different areas of the 3D model's surface, allowing a deeper enhancement of its features. Finally, a Photoshop Software-aided method to generate a virtual tracing of rock art panels is also described.

\subsection{Approaches to study the shape and detail in $3 \mathrm{~d}$ models}

\footnotetext{
${ }^{1}$ http://gfx.cs.princeton.edu/proj/xshade/
} 
FINAL VERSION: Carrero-Pazos, M., Vilas-Estévez, B., Vázquez-Martínez, A. 2018. Digital imaging techniques for recording and analysing prehistoric rock art panels in Galicia (NW Iberia). Digital Applications in Archaeology and Cultural Heritage 8, 35-45.

https://doi.org/10.1016/j.daach.2017.11.003

Since the beginning of the computer technology era, studies about the use of shading to represent shape and detail in 3D models have been gradually appearing, starting from the technical illustration to digital cartography (Docarmo 1976; Horn 1981; Imhof 1982, among others). Since the 90s, scientists have paid more attention to this subject, because the first methods to enhance the 3D model of surface details were being developed at the time. These approaches belong to a branch of different graphic computer sciences frequently called Non-Photorealistic Rendering (NPR) (Gooch 1998; Gooch et. al 1998; Gooch and Gooch et al. 1999, Gooch et al. 1999). In this sense, Miller (1994) worked on the development of algorithms to get local and global shadings, developing the accessibility shading. Furthermore, Zhukov (et al. 1998), developed a first method to represent $3 \mathrm{D}$ scenes in a more realistic way, reproducing the natural light with a light point distributed in the whole of the virtual scene. By 2004, Pharr and Green presented the ambient occlusion technique (based on Landis 2002), which produces images on which the concavities are being represented by toning down the most irregular parts of the surface.

Other branches related to the NPR models were related to the development of lines and contours to generate silhouettes to enhance 3D models. In this sense, different applications of an automated computer process were developed, since the first approaches only included lines, lineal draws (Decarlo et al. 2003) and contours (Decarlo et al. 2004; Rusinkiewicz 2004). In a second stage was the development of additional lines, known as "suggested contours", which strongly carried the shape of an object more precisely and consistently (Burns et al. 2005; Decarlo and Rusinkiewicz 2007).

Another type of approach to represent the relief in a 3D model consists on the decomposition of the surface normals at different levels. We can highlight the normal mapping, a kind of 3D technique which allows us to give more illumination and a more detailed relief to a 3D model surface. It goes further than other types of mapping, like the topological one, also known as "bumb mapping", which works with light simulating a relief on a texture, getting a depth sensation or giving roughness to a plain coloured object $^{2}$. Furthermore, rendering techniques which depict the normals were also developed (Cigoni et al. 2005), methods where the shading can be managed in a single layer to exaggerate or atenuate lessen the surface details. Another technique that has been highly used is the enhancement achieved with the polynomial texture maps (Malzbender, et al., 2006). Following Ammann (et al. 2012, 1482), "these two last techniques have a relevant disadvantage, because they only take into consideration two scales of the normals". In this sense, the solution to this issue can be the exaggerated shading (Rusinkiewicz et al. 2006), in which the multiple scales of the surface normals previously smoothed are computed in order to manage the light source through the 3D model. Shading values are computed on each scale through the Lambertian Shading, combined with a pondered sum to exaggerate the surface of the 3D model, at multiple scales.

The main issue of this approach is that the combination of these multiple scales depend on the election of the light parameters (direction and shading), which makes it difficult to know what kind of particularities we are obtaining. When a deeper

\footnotetext{
${ }^{2}$ See for further information http://freespace.virgin.net/hugo.elias/graphics/x_polybm.htm
} 
FINAL VERSION: Carrero-Pazos, M., Vilas-Estévez, B., Vázquez-Martínez, A. 2018. Digital imaging techniques for recording and analysing prehistoric rock art panels in Galicia (NW Iberia). Digital Applications in Archaeology and Cultural Heritage 8, 35-45.

https://doi.org/10.1016/j.daach.2017.11.003

representation of the surface reliefs is sought, it is preferable to choose the geometrical surface decomposition (Zatzarinni et al. 2009), like the prominent field technique (Kolomenkin et al. 2009), which identifies the main parts of the relief, or, for instance, the fitting techniques (Vergne et al. 2011), which identify the main lines of an object or a space.

\section{STUDY CASES}

\subsection{Preservation problems}

Deterioration is one of the most important issues concerning Galician Bronze Age rock art (Carrera Ramírez 2011). Since research began, a lot has been written about it, but unfortunately only a few researchers have paid attention to conservation issues, for instance, with the definition of a preventive methodology.

These art expressions are sensible to damage, in which both natural agents and the anthropic ones are always the determining factors for their preservation. Due to the loss of most of this heritage, in the last years new prevention methods have been investigated to guarantee the transmission of the rock art to future generations (Carrera Ramírez 2002).

Protective measures have been also put in place, for example, with the design of a new fieldwork sheet which would be able to diagnose the precise state of preservation of the petroglyphs (Carrera Ramírez 1996; Seoane Veiga 2009). On the other hand, it is necessary to define new study systems, prioritising those that do not directly touch the panel or those that manage to clear the inaccuracy that old methodologies sometimes present (Vázquez Martínez et al. 2015).

In this sense, the first method used to study the petroglyphs in Galicia was the freehand draw (Barros Sivelo 1875; Martín Sarmiento 1745), and afterwards, the grid system was developed (Sobrino Lorenzo-Ruza 1947, 1951). Although both methodologies respected the carved panel, other approaches more harmful, like the "modelling clay" or the "frottage" (Anati 1976) were used at the same time. Moreover, the reproduction using plastics was the most utilised method (Seoane Veiga 2009).

Due to the lack of consistence of these methodologies, more rigorous methods were soon needed. The research sought for the innovation by developing new techniques based on photography and digital imaging (Ortiz Sanz et al. 2010; Pereira Uzal 2012).

\subsection{Laxe da Forneiriña II (Campo Lameiro, Pontevedra)}

Located at the Parque Arqueológico del Arte Rupestre, Laxe da Forneiriña II is one of the most relevant rock art panels in Galicia. Although it has been the object of studies by several authors (see i.e. Rey García and Menéndez Fernández 2011), all of them agree in pointing out the existence of an oversized central deer, with a big antler forming a circle. In the lower part there is a small deer, also with an antler, and next to this, an incomplete zoomorphous. By 1997, some authors pointed out that there was a 
FINAL VERSION: Carrero-Pazos, M., Vilas-Estévez, B., Vázquez-Martínez, A. 2018. Digital imaging techniques for recording and analysing prehistoric rock art panels in Galicia (NW Iberia). Digital Applications in Archaeology and Cultural Heritage 8, 35-45.

https://doi.org/10.1016/j.daach.2017.11.003

new motif not known yet, located in front of the main deer (Vázquez Collazo 1997). That motif was eliminated by succeeding authors (Comendador Rey et al. 2008a, b). Nowadays a new calque can be seen at the Park, with a spear shoved on the rum of the main deer (Rey García and Méndez Fernández 2011, 112) (Figure 1).

[Caption] Figure 1. Laxe da Forneiriña II in its current view.

\subsection{Outeiro dos Cogoludos II.6 (Campo Lameiro, Pontevedra)}

Also placed at the Parque Arqueológico de Arte Rupestre de Campo Lameiro, the panel consists of two deer, one of them with an antler. By 1997, Vázquez Collazo presented a calque where a circle between both deer could be observed, with a cruciform carved inside, something that can be seen partially defined at the Park today (based on Comendador Rey et al. 2008, a, b) (Figure 2).

[Caption] Figure 2. Outeiro dos Cogoludos II.6 in its current view.

\section{METHODOLOGY}

The application of three dimensional models in Archaeology has allowed to widen the scope of the geometric survey process, providing high resolution models that can be connected with different resources and historical information. From this point of view the use of 3D models sharply increases the precision and the archaeologist knowledge about the elements compared to the regular bidimensional pictures or hand-made models (Guidi et al. 2014, 55).

\subsection{Dense Photogrammetry}

In this work, photogrammetry Structure from Motion (SfM) was the method used to accurate document the rock art panels, a technique based in a passive sensor which searches through the treatment and process of at least two pictures in 2D from the same scene, from which a computer software produces a three dimensional model (Remondino 2014, 67). Photogrammetry allows the derivation of metric and semantic information from photographs taking into account the calibration of the camera and image orientation. Its main difference compared to active range sensors lies in the 3D cloud derivation: while active range sensors deliver directly the points, in photogrammetry a mathematical processing of the image data is needed to derive a sparse or dense cloud (Remondino 2014).

The most important part of the methodological design was the image acquisition, carried out following the standard principles of overlapping already published (Agisoft LLC 2012; Verhoeven 2011, 71, among many others) (Figure 3). 
FINAL VERSION: Carrero-Pazos, M., Vilas-Estévez, B., Vázquez-Martínez, A. 2018. Digital imaging techniques for recording and analysing prehistoric rock art panels in Galicia (NW Iberia). Digital Applications in Archaeology and Cultural Heritage 8, 35-45.

https://doi.org/10.1016/j.daach.2017.11.003

[Caption]. Figure 3. Survey data: camera locations (Agisoft Photoscan Software). A: Laxe da Forneiriña II. B: Outeiro dos Cogoludos II.6.

For the recording process, a 20 megapixel Sony SLT-A58 commercial reflex camera was used (Figure 4).

[Caption] Figure 4. Camera Information and data characteristics of the photogrammetric study.

In order to obtain accurate metric information from the 3D model, a small scale of 40 cms was placed over the panels, far from the motifs. Once the set of images were taken, the image processing steps started. For this purpose, Agisoft Photoscan worked automatically taking the matches in the 2D images from different perspectives, based on a combination of SfM and a variety of dense multi-view stereo (MVS) algorithms (Ullman 1979; Seitz et al. 2006; Doneus et al. 2011; Verhoeven 2011; Verhoeven et al. 2012; Plets et al. 2012).

The first part of the workflow was the image alignment, which was done using the correlated points among overlapped 2D images and calculating the position and orientation of the cameras. With this information, Photoscan generated a 3D spare point cloud which was manually cleaned up eliminating the residual points. In a second step, an MVS approach calculated a meshed 3D model, and next the 3D model was texturised basing on photographs (Plets et al. 2012, 147). Later, we used the small scale to set two reference points, defining the distance $(40 \mathrm{cms})$ between them to get the 3D model rescaled. From here, the 3D model was exported to a Standard PLY file to be treated with digital enhancement techniques.

\subsection{Digital enhancement techniques}

\subsubsection{Artificial Lights and Radiance Scaling}

In order to have a first idea of the motifs, a preliminary analysis of the untexturised 3D model with artificial lights was used to check the different parts of the panels (Figure 5).

[Caption] Figure 5. Oblique lights over both 3D models, the method used to analyse the motifs at first glance. A: Laxe da Forneiriña II. B: Outeiro dos Cogoludos II.6.

From figure 5 (A), Laxe da Forneiriña II is composed by a central big deer, with two small deer under the main one. In the case of Outeiro dos Cogoludos II.6 (Figure 5: B), 
FINAL VERSION: Carrero-Pazos, M., Vilas-Estévez, B., Vázquez-Martínez, A. 2018. Digital imaging techniques for recording and analysing prehistoric rock art panels in Galicia (NW Iberia). Digital Applications in Archaeology and Cultural Heritage 8, 35-45. https://doi.org/10.1016/j.daach.2017.11.003

three small deer are also highlighted, with an undefined motif in the central part which is not well defined from the different views. On this basis, this kind of analysis always depend on the chosen angle of the light, which causes that some motifs would be better visible than others.

Further methods are, for example, the MeshLab shader Radiance Scaling, which adjusts reflected light intensities in a way that is dependent on both surface curvature and material characteristics. As a result, diffuse shading or highlight variations are correlated with surface feature variations, enhancing surface concavities and convexities instantaneously (Vergne et al. 2010, 1). This technique was used for the first time in 2012 over epigraphs to facilitate the reading of the motifs (Granier et al. 2012). Thanks to its implementation in MeshLab as a shader (Cigoni et al. 2005), a plugin that creates an isosurface perturbed by a noisy isosurface, its use is now widespread among researchers (see i. e. Medici and Rossi 2015; Vilas Estévez et al. 2015, 2017).

Among other options, the Radiance Scaling grey descriptor gives us high interesting results, as the cavities of the 3D model can be highlighted in grey tones (Figure 6: A, C). However, as we have proposed in other works (Vilas Estévez et al. 2017), better results can be achieved with the "Lit Sphere Radiance Scaling" option, wherein a lit sphere encodes the lighting environment and reflective properties into an image of a sphere, and a different sphere can be used for convex and for concave regions (Granier, et al. 2012). Furthermore, instead of using the pre-set spheres accessible in MeshLab, we proposed the use of a red and yellow sphere to get a better visualisation (Figure 6: B, D).

[Caption] Figure 6. The application of Radiance Scaling shader to both rock art panels. A-C: Grey descriptor. B-D: Combination of red and yellow spheres.

One of the remarkable aspects of this technique is that it allows an instant and objective visual approximation to the $3 \mathrm{D}$ model, in which the concavities and convexities are highlighted. In the case of Laxe da Forneiriña II (Figure 6: A-B) under the main deer the existence of a circle motif can be guessed, although the motif is low perceivable. On the other hand, in Outeiro dos Cogoludos II.6 (Figure 6: C-D) the central motif between the small deer is now defined as a circle with an inscribed cross, fully defined in both Radiance Scaling options. However some carvings are still diffuse, such as the antler of the main deer in Outeiro dos Cogoludos II.6 (Figure 6: D). For this reason, in this work the use of exaggerated shading technique is proposed in order to complement the results of Radiance Scaling.

\subsubsection{Exaggerated shading for depicting shape and details}

The exaggerated shading is a technique developed by S. Rusinkiewicz, M. Burns and D. DeCarlo (2006), inspired by methods for cartographic terrain relief. It is focused on a rendering method which starts from an untextured model and dynamically adjusts the 
FINAL VERSION: Carrero-Pazos, M., Vilas-Estévez, B., Vázquez-Martínez, A. 2018. Digital imaging techniques for recording and analysing prehistoric rock art panels in Galicia (NW Iberia). Digital Applications in Archaeology and Cultural Heritage 8, 35-45.

https://doi.org/10.1016/i.daach.2017.11.003

effective position of the light in different areas of the model surface. It can independently reveal the detail by not taking into consideration the surface orientation.

Following the work of S. Rusinkiewicz (et al. 2006), the procedural approach is based on the development of a non-realistic rendering, which is focused on a multiscalar tone shading applied to the whole of the 3D model. The changes in light are different among other approaches, like height exaggeration or the Radiance Scaling. Meanwhile, this method is focused on three kinds of premises about the light (Rusinkiewicz et al. 2006, 1199):

- The lighting is clamped as in a toon shader to emphasize large bends in the surface, as opposed to gradual changes in the slope.

- The lighting is computed at multiple scales (using surface normal smoothed by different amounts) in order to simultaneously convey overall shape and details at different frequencies. The user can control the relative emphasis given to different scales, to yield the desired effect.

- The light direction varies such that it is always "grazing" with respect to the overall orientation of that part of the object, thus bringing out detail.

The software to perform the exaggerated shading technique is Xshade (Figure 7), which needs a set of pre-smoothed versions of the mesh's normals to get the final shading model.

[Caption] Figure 7. 3D model of Laurana's bust, implemented on Xshade (27861 vertices, 6 smoothing levels).

The software is written in $\mathrm{C}++$ under GNU General Public License (GPL), with executables for Windows and Linux available. To use it the user must drag an .xsh file into the program input provided in the package. The .xsh files are precomputed smoothed normal vectors necessary for the technique, and can be obtained using the xshade-make.exe (dragging a 3D model in over the file).

As stated by S. Rusinkiewicz (et al. $2006^{4}$ ), the first column controls the lowest resolution of the shading, determining the multiplier and the threshold used during the shading pass. The second one refers to the proper exaggerated shading technique, also with sliders for the multiplier and the threshold used during the shading pass, but more important a control (scale dep) to emphasise different scales, from -1 (more weight to larger scales) to 2 (more weight to smaller scales). The third column gives the possibility to get a multi-scale mean curvature shading effect. Furthermore, we can use a Colormap function with different implementations to apply to the result of the shading, and also controlling the light direction. Lastly, it is interesting the principal

\footnotetext{
${ }^{3} \mathrm{http} / /$ gfx.cs.princeton.edu/proj/xshade/

${ }^{4}$ Present also in Xshade's readme file.
} 
FINAL VERSION: Carrero-Pazos, M., Vilas-Estévez, B., Vázquez-Martínez, A. 2018. Digital imaging techniques for recording and analysing prehistoric rock art panels in Galicia (NW Iberia). Digital Applications in Archaeology and Cultural Heritage 8, 35-45.

https://doi.org/10.1016/j.daach.2017.11.003

direction based-light adjustment, an effect that moves the light in the plane perpendicular to the smoothed normal, to maximize local contrast (Rusinkiewicz et al. 2006, 1201-1202).

The application of the exaggerated shading technique over Laxe da Forneiriña II 3D model took close to five hours of processing (14 smoothing levels), and Outeiro dos Cogoludos II.6 four and a half (13 smoothing levels). We used a MSi Intel Core (TM) i7-4712 MQ CPU $2.30 \mathrm{GHz}$, with $16 \mathrm{~GB}$ ram and a Nvidia GeForce 820M, working on Windows 10 operating system.

The results of the exaggerated shading technique can be observed in figures 8 and 9 (C) jointly with the standard cosine shading (A) and the mean curvature (B) for comparison. Furthermore, we included the combination of the mean curvature and the exaggerated shading (D), using the stylisation option brown and green.

[Caption] Figure 8. Laxe da Forneiriña II. A: Standard cosine shading; B: Mean curvature; C: Exaggerated shading. D: Combination of mean curvature and exaggerated shading, with stylization option (colormap), brown and green coloured.

[Caption] Figure 9. Outeiro dos Cogoludos II.6. A: Standard cosine shading; B: Mean curvature; C: Exaggerated shading. D: Combination of mean curvature and exaggerated shading, with stylization option (colormap), brown and green coloured.

\subsection{Towards a virtual tracing}

One of the main interests in rock art digital techniques has been the development of enhanced visualisations of depressions in the rock surface (Loendorf 2001; Bednarik 2007; Brady and Gunn 2012; Mudge et al. 2012; Domingo Sanz 2014) but the real challenge is to create methodologies which contribute to the identification and distinction of man-made artwork from natural features on the stone surface. That is something in which some efforts were done, proposing automatic vectorisations of 3D enhanced images, like the edge detection (Clogg and Díaz-Andreu, 2000), but most of the authors consider that the final result should be always achieved using various methods, as it was also proposed here to get a final single recording product.

Starting from the exaggerated shading image, a new calque using Photoshop Software was achieved, working with shades on the whole of the image. The image used was the direct snapshot (.ppm) which can be extracted from Xshade, so the results of the following methodological approach depend on the Xshade's image orientation.

Originally defined by B. Vilas-Estévez, the methodology was firstly described in other work (Carrero-Pazos et al. 2016) and is focused on the use of dodge and burn tool to lighten or darken areas of the image. Based on the traditional darkroom technique for regulating exposure on specific areas of an image, the methodological procedure 
FINAL VERSION: Carrero-Pazos, M., Vilas-Estévez, B., Vázquez-Martínez, A. 2018. Digital imaging techniques for recording and analysing prehistoric rock art panels in Galicia (NW Iberia). Digital Applications in Archaeology and Cultural Heritage 8, 35-45. https://doi.org/10.1016/j.daach.2017.11.003

generally consists on holding back light to lighten an area of the image (dodging) or increasing the exposure to darken areas of the image (burning) (Figure 10). Specifically, the methodology starts with a gradual darken of Xshade's scaled images (Figure 10: A, B), process which is repeated until the whole image is darkened (Figure 10: C). Subsequently, the image is progressively overexposed with light (Figure 10: D), and the virtual tracing is finished when the image is totally overexposed (Figure 10: E).

[Caption] Figure 10. Steps of the methodological procedure applied to obtain a virtual tracing of the studied panels.

\section{RESULTS AND CONCLUSIONS}

From the previous work we can now better analyse the motifs, to see the correspondences with previous calques done with traditional techniques and distinguish possible natural pecks and human ones. Also, at this stage, a new fieldwork analysis was carried out, to check if Xshade's results were defining human made grooves or maybe natural ones.

In both cases the results were clear, as the grooves were drawing well-known naturalistic figures, as the deer are. Thus, regarding Laxe da Forneiriña II (Figure 11), the previous calque done by Tomos Arqueología (Rey García and Méndez Fernández, 2011,112 ) shows some results that are very similar to ours.

[Caption] Figure 11. Laxe da Forneiriña II. A: Following the calque placed at the park (Rey García and Méndez Fernández, 2011, 112); B: Our proposal.

Thanks to the use of exaggerated shading, we could be able to distinguish a closed antler in the main deer. In addition, there is a spear shoved on the rump of the deer, which does not appear on the work of B. Comendador Rey (et al. 2008, a, b) but on the official calque, placed at the Park, it does (Rey García and Méndez Fernández, 2011, 112). A circular motif can also be observed (although in a subtle way), situated just below the head of the great deer.

From a general perspective, the lower motifs are well registered by traditional methods, although some nuances can be pointed like a larger size of the antler placed on the left. There is one new motif, in the left part of the panel although it could not be defined with this methodology, partially perceivable at the field.

The case of Outeiro dos Cogoludos II.6 seems to be more interesting (Figure 12). We have managed to define the central motif, which in the calque of B. Comendador Rey (et al., $2008 \mathrm{a}, \mathrm{b}$ ) did not appear. It is a circle with a cross inside which divides it in four 
FINAL VERSION: Carrero-Pazos, M., Vilas-Estévez, B., Vázquez-Martínez, A. 2018. Digital imaging techniques for recording and analysing prehistoric rock art panels in Galicia (NW Iberia). Digital Applications in Archaeology and Cultural Heritage 8, 35-45. https://doi.org/10.1016/j.daach.2017.11.003

parts. It refers to a much repeated symbol in rock art linked to historical ages (Costas Goberna 2009). Moreover, we have also been able to define the small antler of the central deer.

[Caption] Figure 12. Outeiro dos Cogoludos II.6. A: Following Comendador Rey (2008a, b); B: Our proposal.

On the other hand, a new motif has certainly appeared in the upper part of the panel. It is a new deer not registered in previous works, characterised by a small antler and a little tail.

It is also interesting to note that the starting part of a circular combination in the lower part of the 3D model can be seen, which could be done squeezing the bulges of the rock as it also happens in other cases (Peña Santos and Rey García 2001, 36).

Overall, this work has contributed to precisely register two Bronze Age rock art panels in Galicia. The results of the application of 3D methods to register and study both petroglyphs have resulted in the appearance of new motifs and the correction of the previous calques. Also, the exaggerated shading technique is a useful and fast method to study the grooves of a 3D model, which can be used to complement Radiance Scaling shader results and LiDAR-based analysis (Carrero-Pazos, 2016).

On the other hand, the preliminary analysis with artificial lights is pretty advisable, as it brings a first idea of the engravings and the preservation problems. It is also recommendable the use of Radiance Scaling for its faster application.

Finally, the exaggerated shading and the Photoshop's virtual tracing contribute to current main challenges in digital rock art techniques. Conversely, we must not forget that these techniques have to be linked to the fieldwork, because although new technologies allow us to have a better calque of the motifs, this does not prevent from having to compare and study both tridimensional work and rock in situ. We have to take into consideration, especially with the exaggerated shading, that both carvings and the natural deformations of the rock would be similarly enhanced. Hence, we must do a comparative study of the original motif on the site. In the particular cases studied here, we were able to easy distinguish natural and human made grooves because the lines always defined a naturalistic or geometrical composition. This indicates that there is not a final automatic method which will bring a complete representation of the carved panel -something which is probably impossible to achieve- and only with a complementary and critical work among specialist judgements (e. g. specific research questions, previous experience) and the application of these digital techniques a final calque can be obtained, which should be understood as an interpretative synthesis, more accurate and robust than traditional tracings. 
FINAL VERSION: Carrero-Pazos, M., Vilas-Estévez, B., Vázquez-Martínez, A. 2018. Digital imaging techniques for recording and analysing prehistoric rock art panels in Galicia (NW Iberia). Digital Applications in Archaeology and Cultural Heritage 8, 35-45.

https://doi.org/10.1016/j.daach.2017.11.003

\section{AKNOWLEDGEMENTS}

Authors want to thank Beatriz Comenador Rey and Tomos Arqueología S. L. for providing unpublished material of the studied cases. Also, authors are grateful to both anonymous reviewers which contributed with comments and suggestions to a previous version of this paper. Laurana's 3D model was downloaded from MeshLab webpage (http://meshlab.sourceforge.net).

\section{REFERENCES}

Agisoft LLC 2012. Agisoft PhotoScan user manual professional edition, Version 0.8.3. Moscow.

Ammann, L., Barla, P., Granier, X., Guennebaud, G., Reuter, P. Surface Relief Analysis for Illustrative Shading. Computer Graphics Forum 31 (4), 1481-1490.

Anati, E., 1976. Metodi di rilevamento e di analisi dell'arte rupestre, Capo di Ponte.

Barros Sivelo, R., 1875. Antigüedades de Galicia. Imprenta de D. Domingo Puga, La Coruña.

Bednarik, R. G., 2007. Rock Art Science: The Scientific Study of Palaeoart. Aryan Books International. New Delhi.

Burns, M., Klawe, J., Rusinkiewicz, S., Finkelstein, A., Fecarlo, D., 2005. Line drawings from volume data. ACM Transactions on Graphics (Proceedings of ACM SIGGRAPH 2005) 24(3), 512-518.

Brady, L., Gunn, R., 2012. Digital enhancement of deteriorated and superimposed pigment art: methods and case studies. In McDonald, J., Veth, P. M. (eds.), A Companion to Rock Art. Wiley-Blackwell, Oxford, pp. 627-643.

Caninas, J.C., Henriques, F., Batista, Á., Pires, H., 2011. Pedra das Cruzinhas: notícia de um monólito gravado na fronteira entre os concelhos do Sabugal e da Guarda. Sabucale 3, 35-56.

Carrera Ramírez, F., 1996. Una ficha para la diagnosis del estado de conservación de los petroglifos gallegos. Castrelos 9-10, 97-108.

Carrera Ramírez, F., 2002. La protección del arte prehistórico ibérico, ¿Misión imposible? Arqueoweb: Revista Sobre Arqueología En Internet 4 (3), Retrieved from $\mathrm{http}$ ://pendientedemigracion.ucm.es/info/arqueoweb/pdf/4-3/carrera.pdf. (accessed 17.01.2016).

Carrera Ramírez, F., 2011. El arte parietal en monumentos megalíticos del Noroeste Ibérico. Valoración, diagnóstico, conservación. BAR International Series, 2190, Archaeopress, Oxford. 
FINAL VERSION: Carrero-Pazos, M., Vilas-Estévez, B., Vázquez-Martínez, A. 2018. Digital imaging techniques for recording and analysing prehistoric rock art panels in Galicia (NW Iberia). Digital Applications in Archaeology and Cultural Heritage 8, 35-45.

https://doi.org/10.1016/j.daach.2017.11.003

Carrero-Pazos, M., Vilas-Estévez, B., Vázquez-Martínez, A., 2016. AsTrend: Towards a new method for the study of ancient carvings. Journal of Archaeological Science: Reports 9, 105-119.

Cassen, S., Robin, G., 2010. Recording art on Neolithic stelae and passage tombs from digital photographs. Journal of Archaeological Method and Theory 17, 1-14.

Chandler, J. H., Fryer, J. G., Kniest, H. T., 2005. Non-invasive three-dimensional recording of Aboriginal rock art using cost-effective digital photogrammetry. Rock Art Research 22, 119-130.

Cigoni, P., Scopigno, R., Tarini, M., 2005. A simple normal enhancement technique for interactive non-photorealistic renderings. Computer \& Graphics 29, 125-133.

Clog, P., Díaz-andreu, M. 2000. Digital Image Processing and the Recording of Rock Art. Journal of Archaeological Science 27, 837-843.

Comendador Rey, B., Ferrer Cruz, X., Vázquez Collazo, V., 2008a. Traballos arqueolóxicos de revisión do rexistro dos gravados rupestres de Parada (Campo Lameiro-Pontevedra). Memoria técnica inédita. Tomos Conservación-Restauración, Vigo.

Comendador Rey, B., Ferrer Cruz, X., Vázquez Collazo, V., 2008b. Traballos arqueolóxicos de revisión do rexistro dos gravados rupestres de Parada (Campo Lameiro-Pontevedra). Actuacións Arqueolóxicas. Ano 2008. Xunta de Galicia, A Coruña.

Correia Santos, M.J., Pires, H., Sousa, O., 2014. Nuevas lecturas de las inscripciones del santuario de Panóias (Vila Real, Portugal). Sylloge Epigraphica Barcinonensis (SEBarc) XII, 197-224.

Correia Santos, M. J., Sousa, O., Pires, H., Fonte, J., Gonçalves-Seco, L., 2015. Travelling back in Time to Recapture Old Texts. The use of Morphological Residual Model (M.R.M.) for epigraphic reading: four case studies (CIL 02, 02395a, CIL 02, 02395c, CIL 02, 02476, CIL 02, 05607), Acts of Information Technologies for Epigraphy and Cultural Heritage. Proceedings of the first EAGLE International Conference, Europeana Eagle project. Studi umanistici- Antichistica, Sapienza Universitá Editrice, 437-450.

Costas Goberna, J., 2009. As pedras e os xogos. A orixe dos taboleiros dos xogos galegos. Instituto de Estudios Vigueses, Vigo.

Decarlo, D., Finkelstein, A., Rusinkiewicz, S., Santella, A., 2003. Suggestive Contours for Conveying Shape. ACM Transactions on Graphics (Proc. SIGGRAPH 2003) 22(3), 848-855.

Decarlo, D., Finkelstein, A., Rusinkiewicz, S., Santella, A., 2004. Interactive Rendering of Suggestive Contours with Temporal Coherence. NPAR '04 Proceedings of the third international symposium on Non-photorealistic animation and rendering, 15-145. 
FINAL VERSION: Carrero-Pazos, M., Vilas-Estévez, B., Vázquez-Martínez, A. 2018. Digital imaging techniques for recording and analysing prehistoric rock art panels in Galicia (NW Iberia). Digital Applications in Archaeology and Cultural Heritage 8, 35-45.

https://doi.org/10.1016/j.daach.2017.11.003

Decarlo, D., Rusinkiewicz, S., 2007. Highlight Lines for Conveying Shape. Proceedings of the fifth International Symposium on Non-Photorealistic Animation and Rendering (NPAR), 63-70.

Díaz-Andreu, M., Brooke, C., Rainsbury, M., Rosser, N., 2006. The spiral that vanished: the application of non-contact recording techniques to an elusive rock art motif at Castlerigg stone circle in Cumbria. Journal of Archaeological Science 33 (11), 1580-1587.

Díaz-Guardamino M., Wheatley D. (2013). Rock Art and Digital Technologies: the Application of Reflectance Transformation Imaging (RTI) and 3D Laser Scanning to the Study of Late Bronze Age Iberian Stelae, MENGA. Revista de Prehistoria de Anadalucia 4, 187-203.

Díaz-Guardamino, M., García Sanjuán, L., Wheatley, D., Rodríguez Zamora, V. 2015. RTI and the study of engraved rock art: A re-examination of the Iberian south-western stelae of Setefilla and Almadén de la Plata 2 (Seville, Spain). Digital Applications in Archaeology and Cultural Heritage 2, 41-54.

Docarmo, M. P., 1976. Differential geometry of curves and surfaces. Prentice-Hall, New Yersey.

Domingo Sanz, I., 2014. Rock art recording methods: from traditional to digital. In Smith, C. (ed.), Encyclopedia of Global Archaeology. Springer, New York, pp. 63516357.

Domingo, I., Villaverde, V., López-Montalvo, E., Lerma, J. L., Cabrelles, M., 2013. Latest developments in rock art recording: towards an integral documentation of Levantine rock art sites combining $2 \mathrm{D}$ and 3D recording techniques. Journal of Archaeological Science 40, 1879-1889.

Doneus, M., Verhoeven, G., Fera, M., Briese, C., Kucera, M., W. Neubauer, W. 2011. From deposit to point cloud - a study of low-cost computer vision approaches for the straightforward documentation of archaeological excavations. Paper presented at XXIII CIPA Symposium. Prague, Czech Republic, ICOMOS.

Duffy, S. M., 2013. Multi-Light Imaging for Heritage Applications. English Heritage Swindon.

Earl, G., Beale, G., Martinez, K., Pagi, H., 2010. Polynomial Texture Mapping and Related Imaging Technologies for the Recording, Analysis and Presentation of Archaeological Materials. International Society for Photogrammetry and Remote Sensing XXXVIII (Part 5), 218-223.

El-hakim, S., Fryer, J., Picard, M., Whiting, E., 2004. Digital recording of aboriginal rock art. In 10th International Conference on Virtual Systems and Multimedia (VSMM), Ogaki City, Gifu, Japan, 17e19 Nov. 2004, 344-353.

Escarcena, J. C., De Castro, E. M., García, J. L. P., Calvache, A. M., Del Castillo, T. F., García, J. D., Cámara, M. U., Castillo, J. C., 2011. Integration of photogrammetric and 
FINAL VERSION: Carrero-Pazos, M., Vilas-Estévez, B., Vázquez-Martínez, A. 2018. Digital imaging techniques for recording and analysing prehistoric rock art panels in Galicia (NW Iberia). Digital Applications in Archaeology and Cultural Heritage 8, 35-45.

https://doi.org/10.1016/i.daach.2017.11.003

terrestrial laser scanning techniques for heritage documentation. Virtual Archaeology Review 2, 53-57.

Gil Docampo, M.L., Ortiz Sanz, J., Martínez Rodríguez, S., Vázquez, B., Rego Sanmartín, T., 2011. The detection of petroglyphs through digital image processing. The particular case of the stone inside the chapel of Saint Bartolomé (Lugo-Spain). Proceedings of the IMProVe 2011, International Conference on Innovative Methods in Product Design (Venice, Italy), 363-367.

Gooch, A.A., 1998. Interactive Non-Photorealistic Technical Illustration. Master's Thesis. Department of Computer Science, University of Utah.

Gooch, A.A., Gooch, B., Shirley, P., Cohen, E., 1998. A non-photorealistic lighting model for automatic technical illustration. Proceedings of the 21st Annual Conference on Computer Graphics and Interactive Techniques (SIGGRAPH 1994, Orlando), 447452.

Gooch, A. A., Gooch, B., Shirley, P., Cohen, E., 1999. Using Non-Photorealistic rendering to communicate shape. In green, S.E. (ed.), SIGGRAPH'99 Course Notes on Non-Photorealistic Rendering. ACM SIGGRAPH, New York.

Gooch, B., Sloan, P. -P. J., Gooch, A., Shirley, P., Riesenfeld, R., 1999. Interactive technical illustration. $I 3 D-A C M, 31-38$.

Granier, X., Vergne, R., Pacanowsky, R., Barla, P., Reuter, P., 2012. Enhancing Surface features with the radiance scaling MeshLab plugin. In Graeme, E., sly, T., Chrysanthi, A., Murrieta-flores, P., Papadopoulos, C., Romanowska, I., Wheatley, D. (eds.), Archaeology in the Digital Era, Volume II, Amsterdam University Press, Amsterdam, 417-422.

Grimaud, V. 2015. Réexplorer et valoriser les architectures funéraires monumentales du Néolithique de l'Ouest de la France. Etude du cairn de Gavrinis. Université de Nantes Angers le Mans: Nantes (Unpublished PhD Dissertation).

Guidi, G., Ruso, M., Angheleddu, D., 2014. 3D survey and virtual reconstruction of archaeological sites. Digital Applications in Archaeology and Cultural Heritage 1(2), 55-69.

Horn, B.K.P., 1981. Hill shading and the reflectance map. Proceedings IEEE 69 (1), 1447.

Imhof, E., 1982. Cartographic relief presentation. Walter De Gruyter, New York.

Landis, H., 2002. Production-ready global illumination. Course 16 notes, SIGGRAPH 2002.

Lerma, J.L., Navarro, S., Cabrelles, M., Villaverde, V., 2010. Terrestrial laser scanning and close range photogrammetry for $3 \mathrm{D}$ archaeological documentation: the Upper Palaeolithic Cave of Parpalló as a case study. Journal of Archaeological Science 37, 499-507. 
FINAL VERSION: Carrero-Pazos, M., Vilas-Estévez, B., Vázquez-Martínez, A. 2018. Digital imaging techniques for recording and analysing prehistoric rock art panels in Galicia (NW Iberia). Digital Applications in Archaeology and Cultural Heritage 8, 35-45.

https://doi.org/10.1016/j.daach.2017.11.003

Loendorf, L., 2001. Rock art recording. In whitley, D. S. (ed.), Handbook of Rock Art Research. Altamira Press, Walnut Creek, 55-79.

Lymer, K., 2015. Image processing and visualisation of rock art laser scans from Loup's Hill, County Durham. Digital Applications in Archaeology and Cultural Heritage 2, 155-165.

Malzbender, T., Gelb, D., Wolters, H., Zuckerman, B., 2000. Enhancement of shape perception by Surface Reflectance Transformation. Tech. Rep. HPL- 2000- 38R1. Hewlett-Packard Laboratories, , Palo Alto, California.

Malzbender, T., Gelb, D., Wolters, H., Zuckerman, B., 2001. Polynomial texture maps. In SIGGRAPH '01: Proceedings of the 28th Annual Conference on Computer Graphics and Interactive Techniques (New York, USA, 2001), 519-528.

Malzbender, T., Wilburn, B., Gelb, D., Ambrisco, B., 2006. Surface enhancement using real-time photogrammetric stereo and reflectance transformation. Eurographics Symposium on Rendering, 245-250.

Mañana Borrazás, P., Blanco Rotea, R., Rodríguez Paz, A., 2009. La documentación geométrica de elementos patrimoniales con láser escáner terrestre. La experiencia del Lapa en Galicia. Cuadernos de Estudios Gallegos 65, 33-65.

Martín Sarmiento, F., 1745. Viaje a Galicia (1975th Ed.). Museo de Pontevedra.

Martínez Rodríguez, S., Ortiz Sanz, J.; Gil Docampo, M. L; Meijide Cameselle, G. Rego Sanmartín, T., 2012. El modelado 3D de petroglifos mediante escáner fotogramétrico. In Fábregas Valcarce, R., Rodríguez Rellán, C. (eds.), A Arte Rupestre no Norte do Barbanza. Andavira editora, Santiago de Compostela, 139-146.

Medici, P., Rossi, G., 2015. Valcamonica 3.0: a new dimension in rock art recording. From tracing to structure from motion and postprocessing. In Troletti, F. (ed.), Research Perspectives on Prehistoric Art, Proceedings of the XXVI Valcamonica Symposium, Capo di Ponte (9th -12th September 2015), Ed. Del Centro, 163-168.

Miller, G.S.P., 1994. Efficient algorithms for local and global accessibility shading. In Proceedings of the 21st Annual Conference on Computer Graphics and Interactive Techniques, (SIGGRAPH 1994, Orlando), 319-326.

Montero, I., Rodríguez, A., Vicent, J. M., Cruz, M., 1998. Técnicas digitales para la elaboración de calcos de Arte Rupestre. Trabajos de Prehistoria 55 (1), 155-169.

Mudge M., Malzbender T., Schroer C., Lum M. (2006). New Reflection Transformation Imaging Methods for Rock Art and Multiple-Viewpoint Display. In: Ioannides, M., Arnold, D., Niccolucci, F., Mania, K. (eds.), The 7th International Symposium on Virtual Reality, Archaeology and Cultural Heritage VAST (2006), 195-202.

Mudge, M., Schroer, C., Noble, T., Matthews, N., Rusinkiewicz, S., Toler-Franklin, C., 2012. Robust and Scientifically Reliable Rock Art Documentation from Digital 
FINAL VERSION: Carrero-Pazos, M., Vilas-Estévez, B., Vázquez-Martínez, A. 2018. Digital imaging techniques for recording and analysing prehistoric rock art panels in Galicia (NW Iberia). Digital Applications in Archaeology and Cultural Heritage 8, 35-45.

https://doi.org/10.1016/j.daach.2017.11.003

Photograps. In Mcdonald, J., Veth, P. (eds.), A Companion to Rock Art. Blackwell Publishing, Malden, USA.

Olsen S.L., Bryant T. (2013). Stories in the Rock: Exploring Saudi Arabian Rock Art. Carnegie Museum of Natural History Pittsburg [see also http://saudi-archaeology.com/, consulted 16/01/2017].

Ortiz Sanz, J., Gil Docampo, M., Martínez Rodríguez, S., Rego Sanmartín, M. T., Meijide Cameselle, G., 2010. A Simple Methodology for Recording Petroglyphs using Low-Cost Digital Image Correlation Photogrammetry and Consumer Grade Digital Cameras. Journal of Archaeological Science 37, 3158-3169.

Peña Santos, A., Rey García, M., 2001. Petroglifos de Galicia. Vía Láctea, A Coruña.

Pereira Uzal, J. M., 2012. Algunas experiencias con Reflectance Transformation Imaging (RTI) en grabados rupestres. Retrieved from http://www.jpereira.net/apuntesbreves/algunas-exp.

Pharr, M., Green, S., 2004. Ambient Occlusion. In: F. Randima (ed.), GPU Gems. Addison-Wesley, 279-292.

Pires, H., Fonte, J., Gonçalves-Seco, L., Correia Santos, M. J., Sousa, O., 2014. Morphological Residual Model. A Tool for Enhancing Epigraphic Readings of Highly Erosioned Surfaces. In EAGLE- Information Technologies for Epigraphy and Cultural Heritage in the Ancient World. Paris, 133-144.

Pires, H., Martínez Rubio, J., Elorza Arana, A., 2015. Techniques for revealing 3D hidden archaeological features: morphological residual models as a virtual-polynomial texture maps. In The International Archives of the Photogrammetry, Remote Sensing and Spatial Information Sciences (3D Virtual Reconstruction and Visualization of Complex Arquitectures, 25-27 February 2015, Avila, Spain), 415-421.

Pitts, M., Miles, J., Pagi, H., Earl, G., 2014a. Hoa Hakananai'a: a new study of an Easter Island Statue in the British Museum. Antiquity Journal 94, 291-321.

Pitts, M., Miles, J., Pagi, H., Earl, G., 2014b. New applications of photogrammetry and reflectance transformation imaging to an Easter Island statue. Antiquity 88, 596-605.

Plets, G., Verhoeven, G., Cheremisin, D., Plets, R., Bourgeois, J., Stichelbaut, B., Gheyle, W., De Reu, J., 2012. The deteriorating preservation of the Altai rock art: Assesing three-dimensional image based modelling in rock art research and management. Rock Art Research 29 (2), 139-156.

Remondino, F., 2014. Photogrammetry. Basic Theory. In Remondino, F., Campana, S. (ed.), $3 D$ recording and modelling in Archaeology and Cultural Heritage. BAR International Series, Oxford, 63-72.

Rey García, J.M., Méndez Fernández, F., 2011. Parque Arqueolóxico da Arte Rupestre de Campo Lameiro, Guía de Visita. Consellería de Cultura e Turismo, Dirección Xeral de Patrimonio Cultural. Xunta de Galicia, Santiago de Compostela. 
FINAL VERSION: Carrero-Pazos, M., Vilas-Estévez, B., Vázquez-Martínez, A. 2018. Digital imaging techniques for recording and analysing prehistoric rock art panels in Galicia (NW Iberia). Digital Applications in Archaeology and Cultural Heritage 8, 35-45.

https://doi.org/10.1016/i.daach.2017.11.003

Robin, G., 2015. Editorial. Digital Applications in Archaeology and Cultural Heritage $2,35-40$.

Robson, K.A., Chalmers, A., Saigol, T., Green, C., D’errico, F., 2001. An automated laser scan Survey of the Upper Palaeolithic rock shelter of Cap Blanc. Journal of Archaeological Science 28, 283-289.

Rusinkiewicz, S., 2004. Estimating Curvatures and Their Derivatives on Triangle Meshes. In 3DPVT '04 Proceedings of the 3D Data Processing, Visualization, and Transmission, 2nd International Symposium, 486-493.

Rusinkiewicz, S., Burns, M., Decarlo, D., 2006. Exaggerated shading for depicting shape and detail. ACM Transactions on Graphics - TOG 25(3), 1199-1205.

Scopigno, R., Callieri, M., Cignoni, P., Corsini, M., Dellepiane, M., Ponchio, F., Ranzuglia, G. 2011. 3D models for cultural heritage: Beyond plain visualization. IEEE Computer 44(7), 48-55. http://doi.org/10.1109/MC.2011.196

Seitz, S. M., B. Curless, J. Diebel, D. Scharstein, Szeliski, R. 2006. A comparison and evaluation of Multiview stereo reconstruction algorithms. Paper presented at 2006 IEEE Computer Society Conference on Computer Vision and Pattern Recognition.

Seoane Veiga, Y., 2009. Propuesta metodológica para el registro del Arte Rupestre de Galicia. CSIC-Incipit, Santiago de Compostela.

Simpson, A., Clogg, P., Díaz-Andreu, M., Larkman, B., 2004. Towards threedimensional non-invasive recording of incised rock art. Antiquity 78 (301), 692-698.

Sobrino Lorenzo-Ruza, R., 1947. Un petroglifo en Mallos, Ayuntamiento de Teo (Coruña). Boletín de La Comisión Provincial de Monumentos Históricos y Artísticos de Lugo III (23-24), 61-64.

Sobrino Lorenzo-Ruza, R., 1951. El petroglifo de Oca en Ames (Coruña). Boletín de La Real Academia Gallega XXV, 260-269.

Ullman, S. 1979. Interpretation of structure from motion. Proceedings of the Royal Society of London Series B, Biological Sciences 203, 405-426.

Vázquez Collazo, S., 1997. Traballos de localización e rexistro dos gravados rupestres de ámbito espacial do futuro do parque temático de arte rupestre de Paredes (Campo Lameiro, Pontevedra). Memoria Técnica inédita. Dirección Xeral de Patrimonio Cultural, Santiago de Compostela.

Vázquez Martínez, A., Vilas Estévez, B., Carrero-Pazos, M., 2015. Sobre as técnicas de reprodución dos gravados rupestres galaicos ao aire libre. Férvedes 8(Actas do III Congreso Internacional de Arqueoloxía de Vilalba (Vilalba, Lugo, 20-23/07/2015), 17 24. 
FINAL VERSION: Carrero-Pazos, M., Vilas-Estévez, B., Vázquez-Martínez, A. 2018. Digital imaging techniques for recording and analysing prehistoric rock art panels in Galicia (NW Iberia). Digital Applications in Archaeology and Cultural Heritage 8, 35-45.

https://doi.org/10.1016/i.daach.2017.11.003

Verhoeven, G. 2011. Taking computer vision aloft - archaeological three-dimensional reconstructions from aerial photographs with Photoscan. Archaeological Prospection $18,67-73$.

Verhoeven, G., Taelman, D., Vermeulen, F. 2012. Computer vision-based orthophote mapping of complex archaeological sites: the ancient quarry of Pitaranhia (PortugalSpain). Archaeometry, doi/10.1111/j.1475-4754.2012.00667. Accessed 3 April 2012.

Vergne, R., Pacanowski, R., Barla, P., Granier, X., Shlick, C., 2010. Radiance Scaling for Versatile Surface Enhancement. In I3D '10 Proceedings of the 2010 ACM SIGGRAPH symposium on Interactive 3D Graphics and Games. ACM 143-150.

Vergne, R., Vanderhaegue, D., Chen, J., Barla, P., Granier, X., Schlick, C., 2011. Implicit brushes for stylized line-based rendering. Computer Graphics Forum 30 (2), 513-522.

Vicent, J. M., Montero, I., Rodríguez, A., Martínez, I., Chapa, T., 1996. Aplicación de la imagen multiespectral al estudio y conservación del arte rupestre postpaleolítico. Trabajos de Prehistoria 53 (2), 19-35.

Vilas Estévez, B., Vázquez Martínez, A., Carrero Pazos, M., 2015. The Use of Photogrammetric Techniques for Recording the Rock Art Carving at Campo Lameiro (Galicia, Northern Spain). 43rd Computer Applications and Quantitative Methods in Archaeology "KEEP THE REVOLUTION GOING” Conference (CAA 2015 SIENA). Poster presentation.

Vilas Estévez, B., Carrero Pazos, M., Vázquez Martínez, A., 2017. Going further: (Re)discovering rock art carvings with photogrammetric techniques in Galicia (Northwest Iberian Peninsula). In Ippolito, A., Cigola, M. (eds.), Handbook of Research on Emerging Technologies for Digital Preservation and Information Modeling, IGI Global, Hershey PA, USA, 175-200.

Zatzarinni, R., Tal, A., Shamir, A., 2009. Relief Analysis and Extraction. Proceedings of SIGGRAPH, Asia. ACM Transactions Graphics 28(5), 1-10.

Zhukov, S., Iones, A., Kronin, G., 1998. An ambient light illumination model. In Drettakis, G., Max., N. (eds.), Rendering Techniques '98, Proceedings of the Eurographics Workshop in Vienna, Austria, June 29-July 1, 1998. Springer, New York, 45-56. 


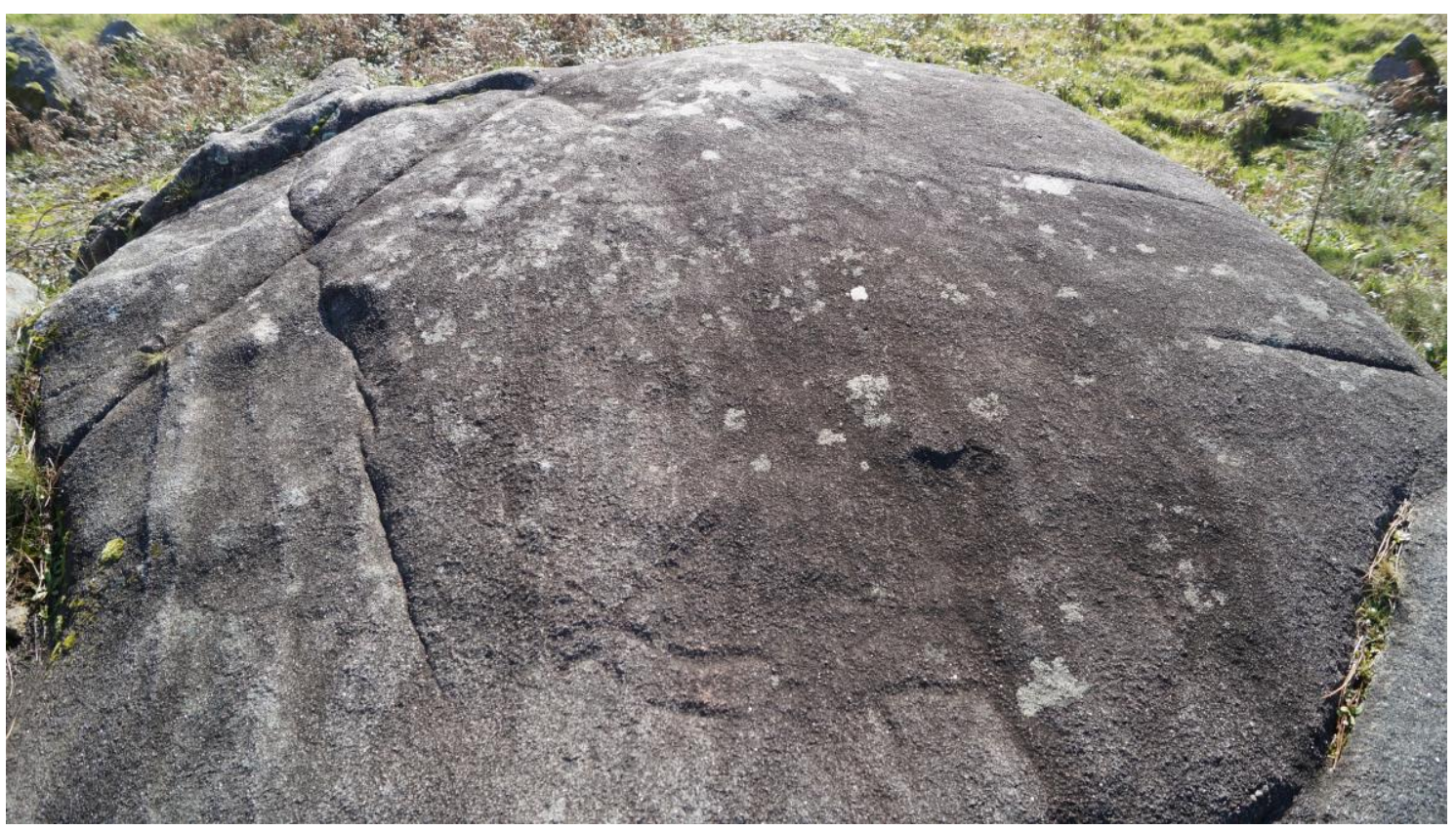

Figure 1. Laxe da Forneiriña II in its current view.

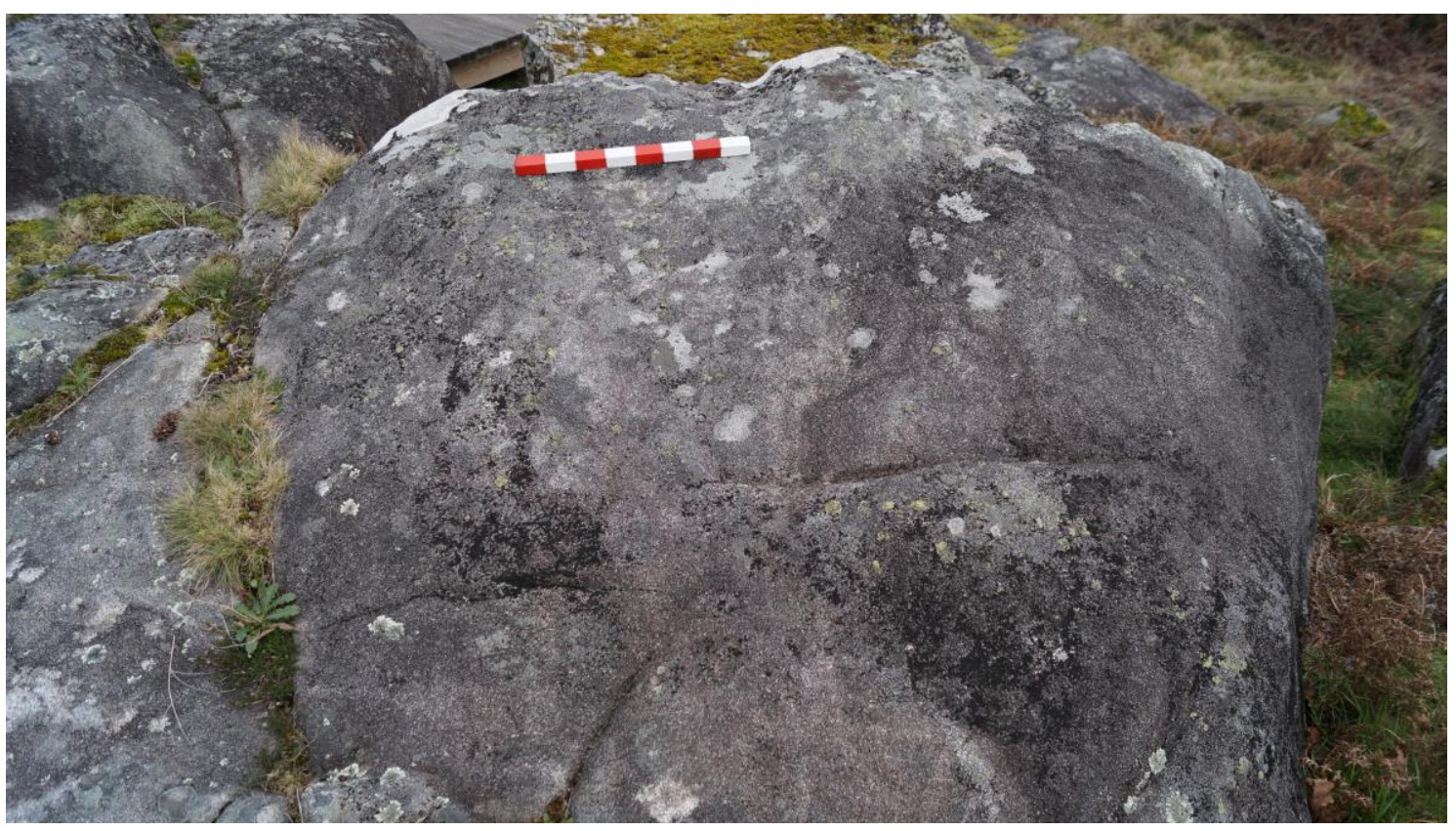

Figure 2. Outeiro dos Cogoludos II.6 in its current view. 

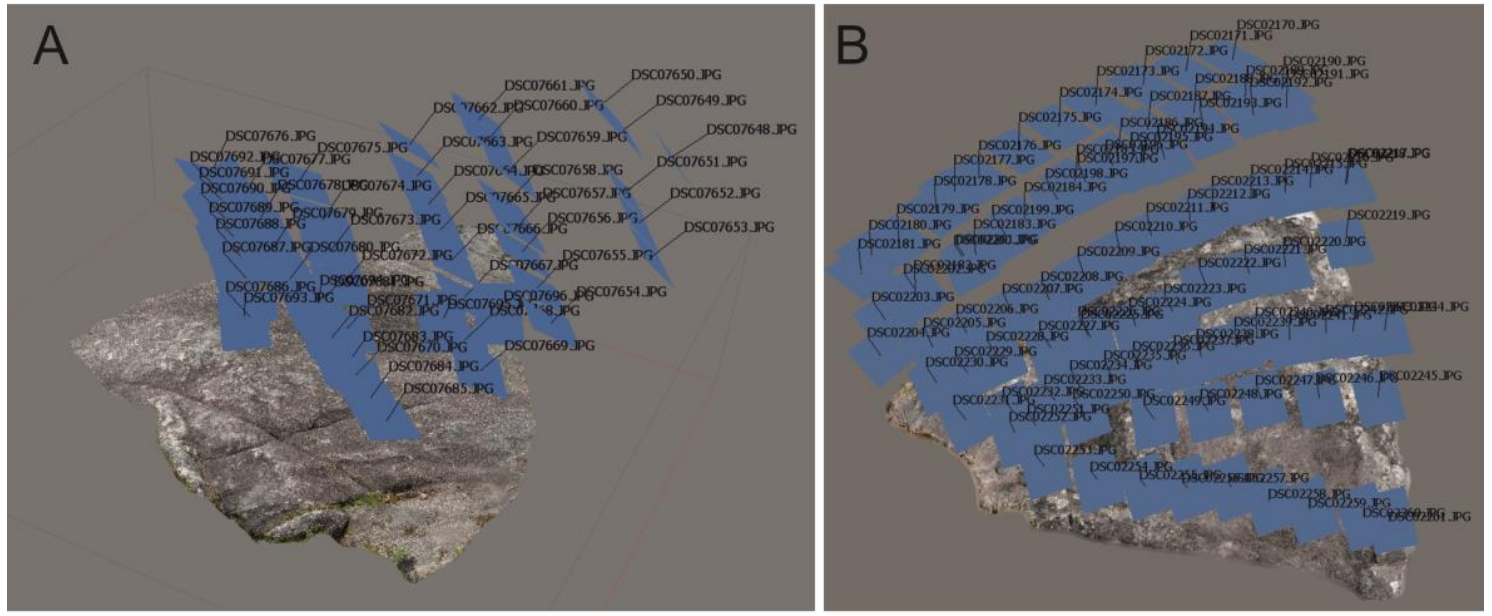

Figure 3. Survey data: camera locations (AgiSoft Photoscan Software). A: Laxe da Forneiriña II. B: Outeiro dos Cogoludos II.6.

\begin{tabular}{|c|c|c|}
\hline \multicolumn{3}{|c|}{ - Camera: Sony SLT-A58 - } \\
\hline Resolution & \multicolumn{2}{|l|}{$5456 \times 3064$} \\
\hline Pixel size & \multicolumn{2}{|l|}{4.60959 x 4.60959 um } \\
\hline F point & \multicolumn{2}{|l|}{$\mathrm{f} / 5$} \\
\hline Exposition time & \multicolumn{2}{|l|}{$1 / 500 \mathrm{~s}$} \\
\hline ISO Velocity & \multicolumn{2}{|l|}{ ISO-200 } \\
\hline Exposure compensa & \multicolumn{2}{|l|}{0 pass } \\
\hline Focal length & \multicolumn{2}{|l|}{$18 \mathrm{~mm}$} \\
\hline Maximum opening & \multicolumn{2}{|l|}{3.6171875} \\
\hline \multicolumn{3}{|c|}{ Images } \\
\hline Dimensions & \multicolumn{2}{|l|}{3872 x 2176 pix } \\
\hline Resolution & \multicolumn{2}{|l|}{350 ppp } \\
\hline Format & \multicolumn{2}{|l|}{ JPG } \\
\hline \multicolumn{3}{|c|}{ - 3D model reconstruction - } \\
\hline Study Case & \multicolumn{2}{|c|}{ Laxe da Forneiriña II $\begin{array}{c}\text { Outeiro dos Cogoludos } \\
\text { II.6 }\end{array}$} \\
\hline Number of Images & 49 & 93 \\
\hline Resolution & $0.00219912 \mathrm{~m} / \mathrm{pix}$ & $0.00145438 \mathrm{~m} / \mathrm{pix}$ \\
\hline Tie-points & 348343 & 1005501 \\
\hline Projections & 958305 & 2887466 \\
\hline Error & 0.308992 pix & 0.265548 pix \\
\hline Image overlap & $>9$ & $>9$ \\
\hline 3D model vertices & 1844684 & 1365920 \\
\hline $3 D$ model faces & 3684521 & 2727318 \\
\hline
\end{tabular}

Figure. 4. Camera Information and data characteristics of the photogrammetric study. 

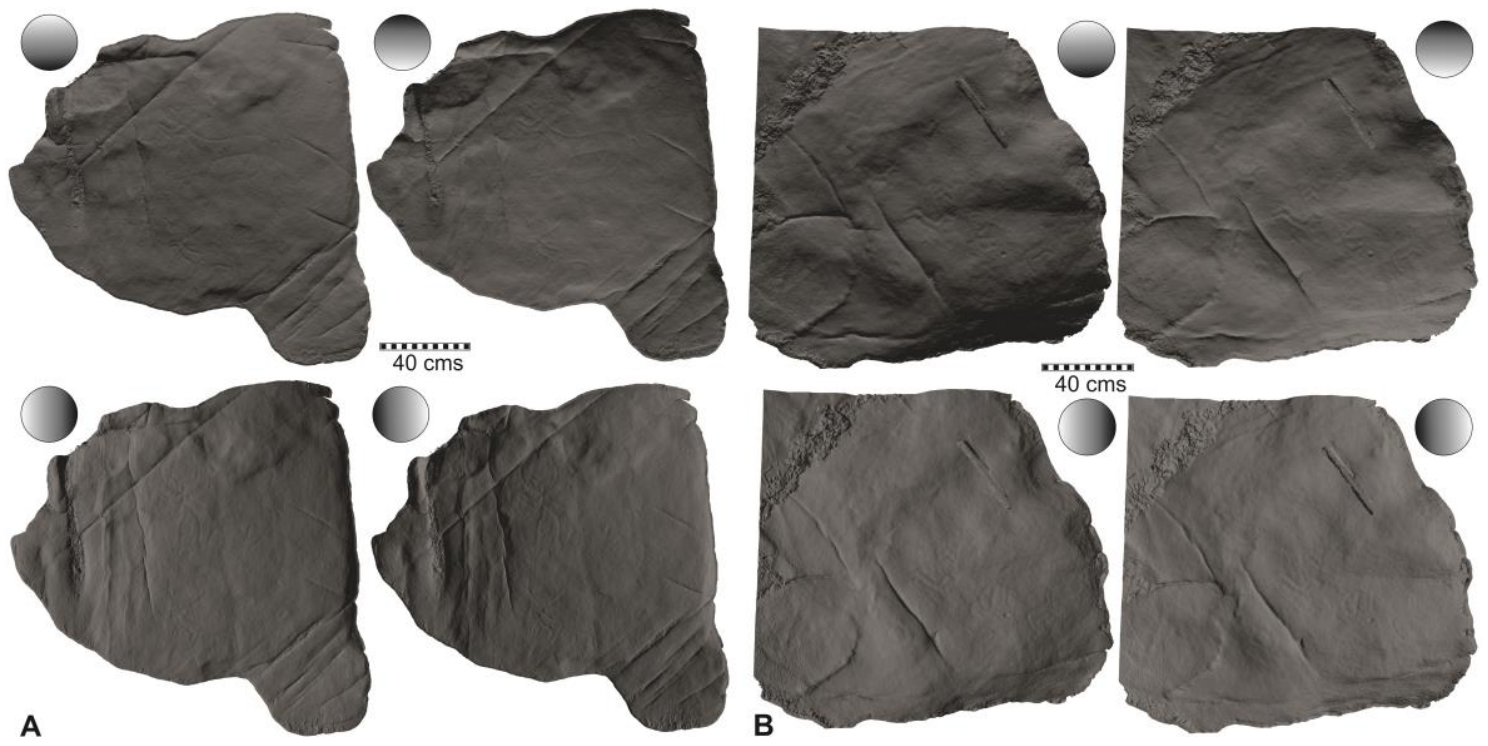

Figure 5. Oblique lights over both 3D models, the method used to analyse the motifs at first glance. A: Laxe da Forneiriña II. B: Outeiro dos Cogoludos II.6.

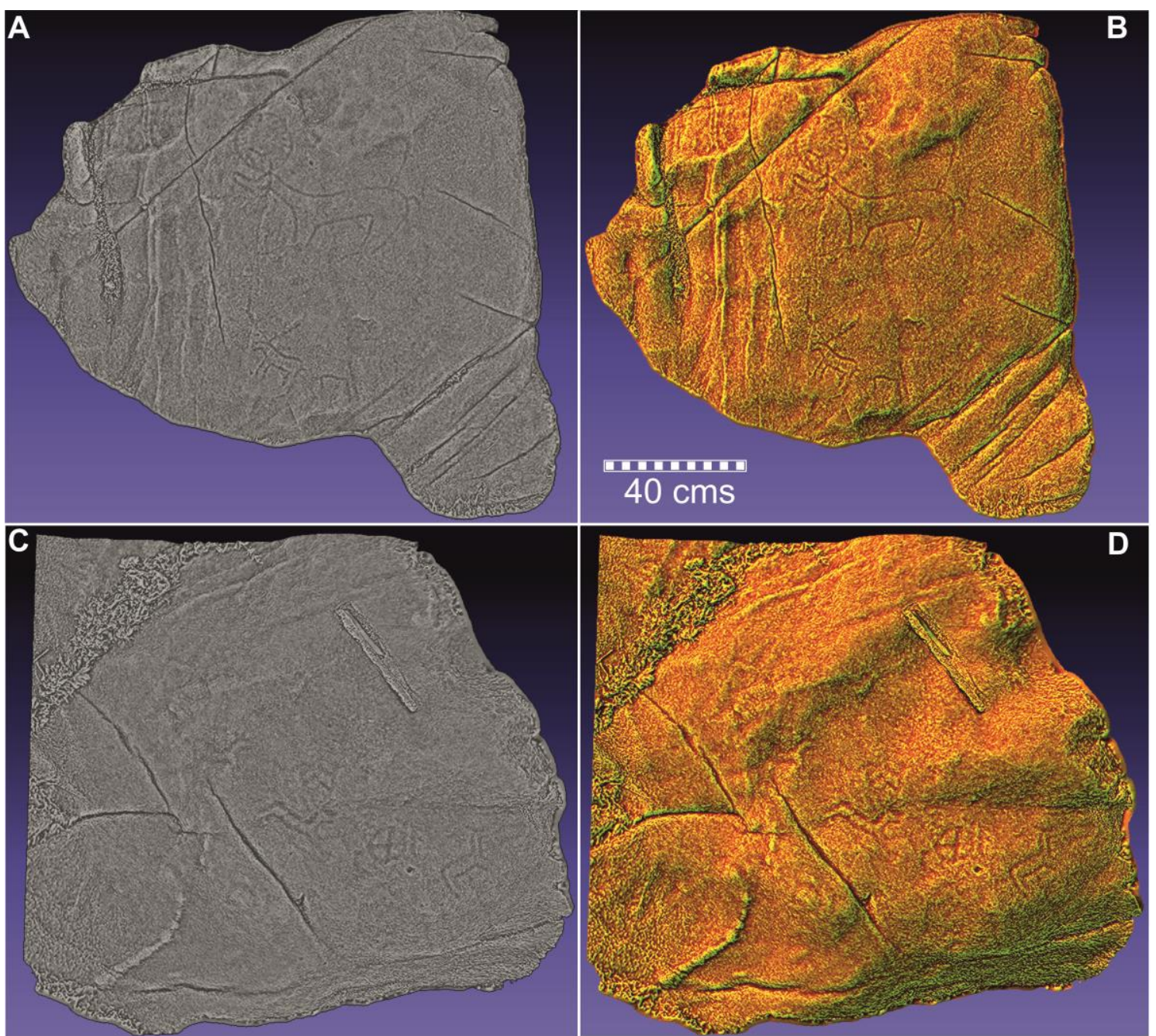

Figure 6. The application of Radiance Scaling shader to both rock art panels. A-C: Grey descriptor. B-D: Combination of red and yellow spheres. 


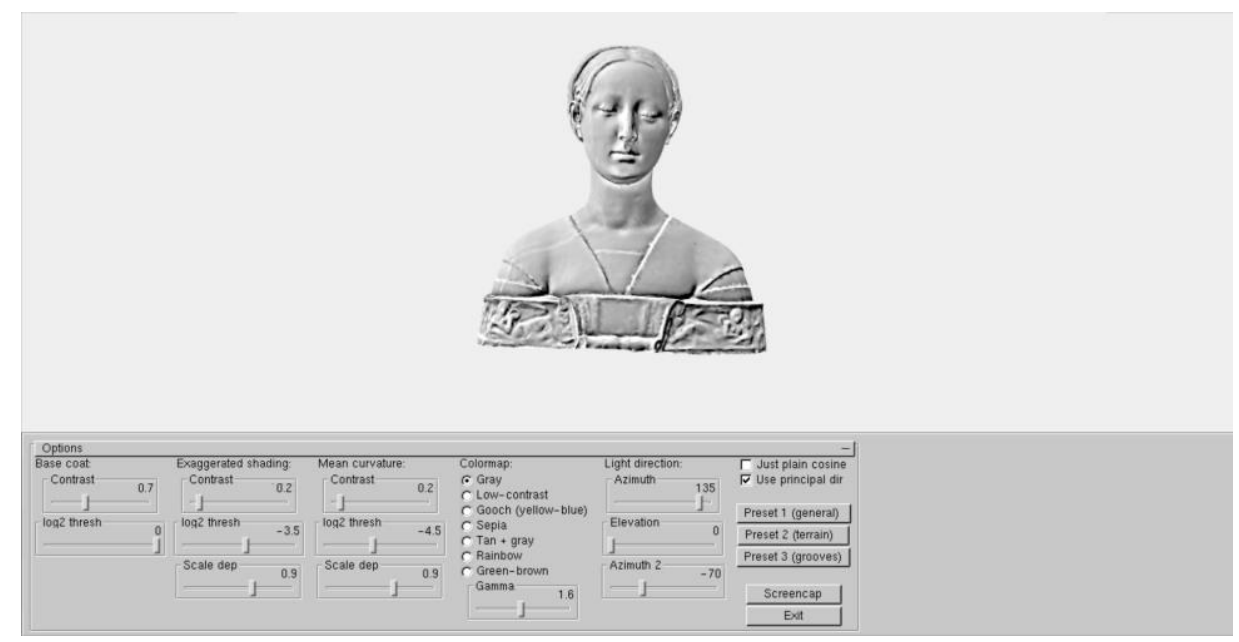

Figure 7. 3D model of Laurana's bust, implemented on Xshade (27861 vertices, 6 smoothing levels).

A
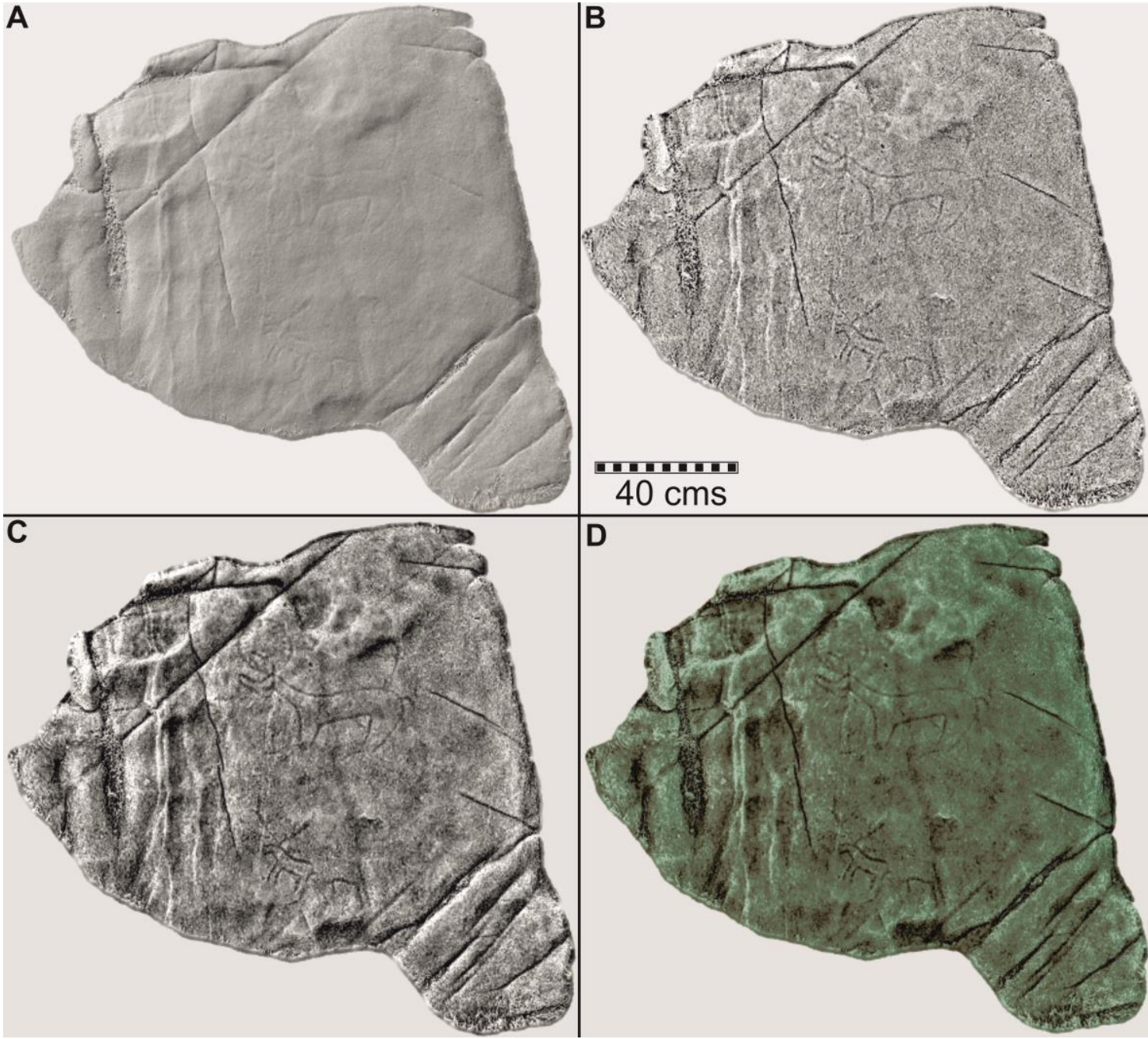

Figure 8. Laxe da Forneiriña II. A: Standard cosine shading; B: Mean curvature; C: Exaggerated shading. D: Combination of mean curvature and exaggerated shading, with stylization option (colormap), brown and green coloured. 


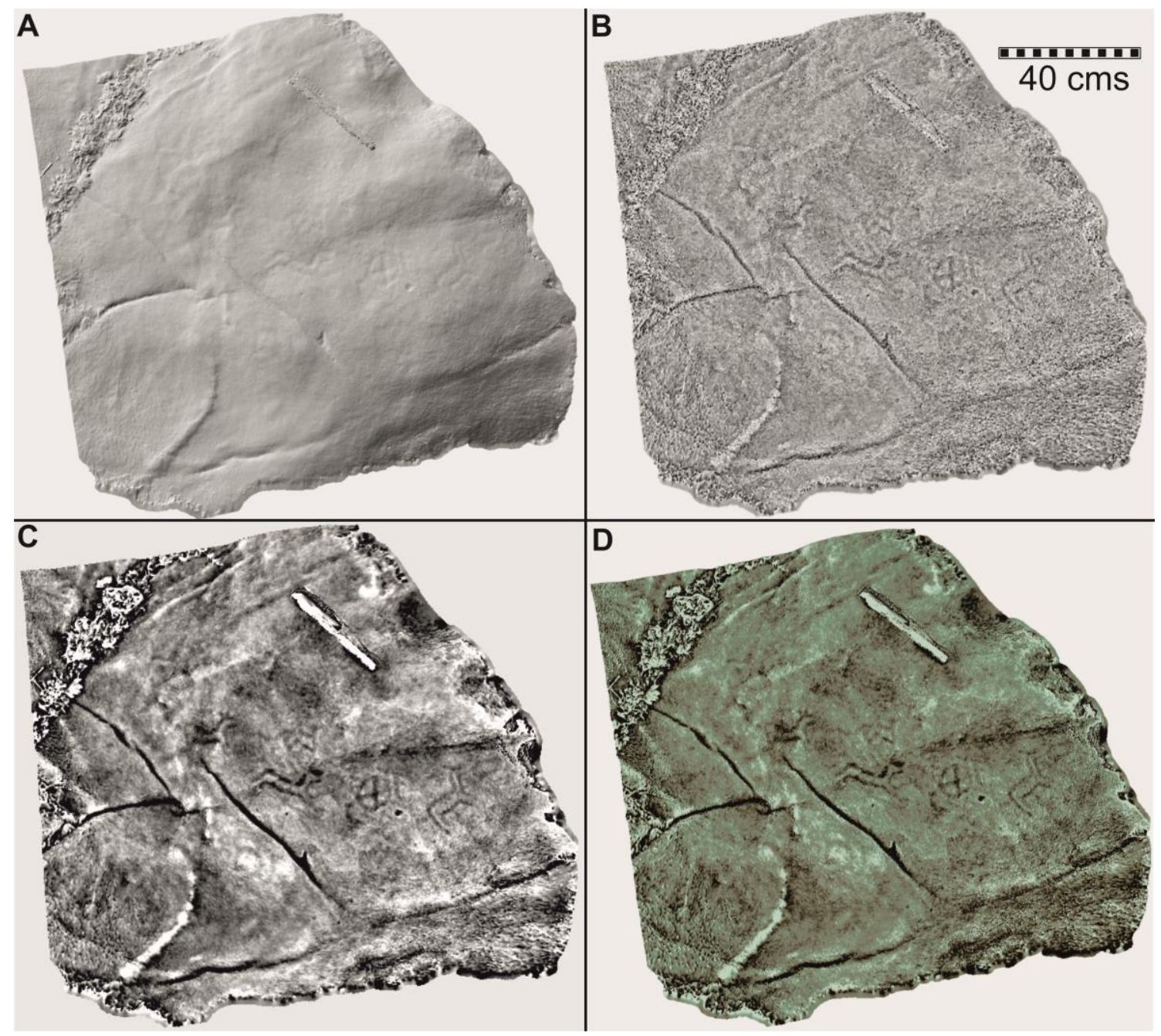

Figure 9. Outeiro dos Cogoludos II.6. A: Standard cosine shading; B: Mean curvature; C: Exaggerated shading. D: Combination of mean curvature and exaggerated shading, with stylization option (colormap), brown and green coloured. 


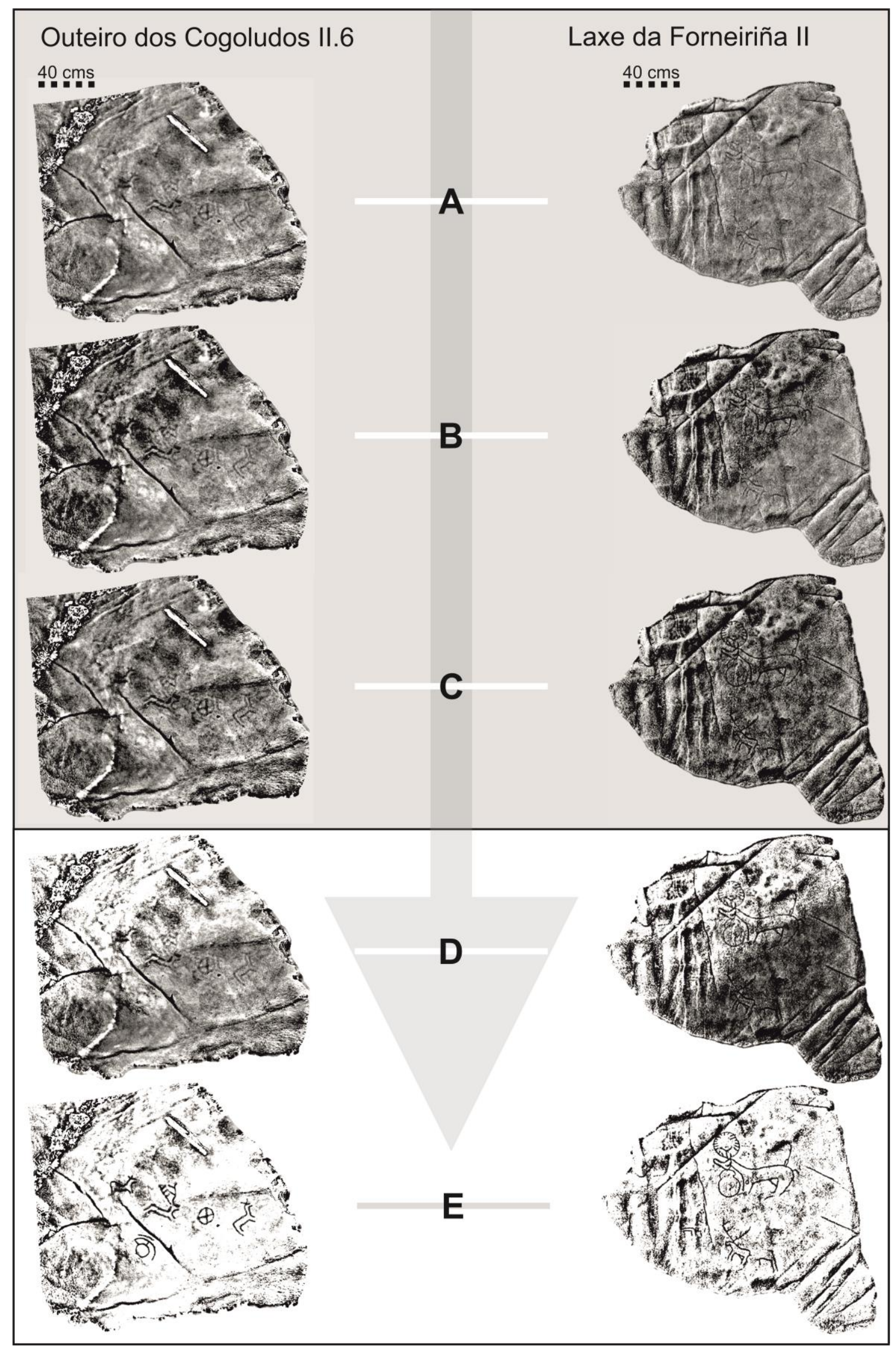

Figure 10. Steps of the methodological procedure applied to obtain a virtual tracing of the studied panels. 

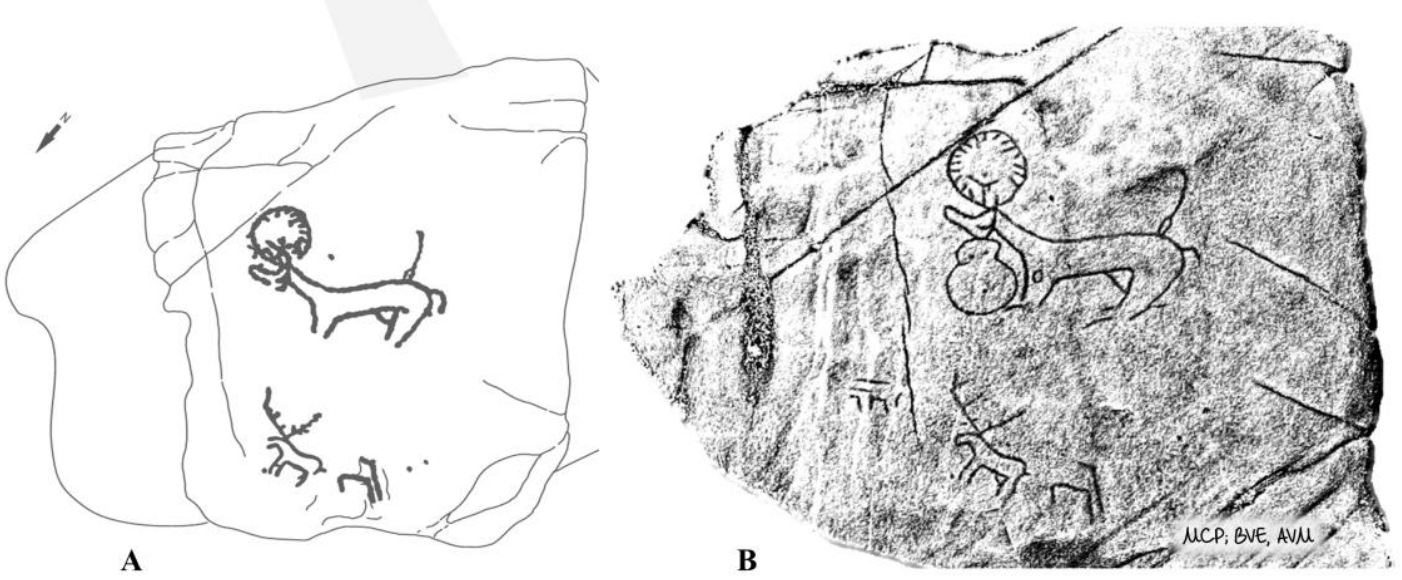

Figure 11. Laxe da Forneiriña II A: Following the calque placed at the park (Rey García, Menéndez Fernández, 2011, 112); B: Our proposal.

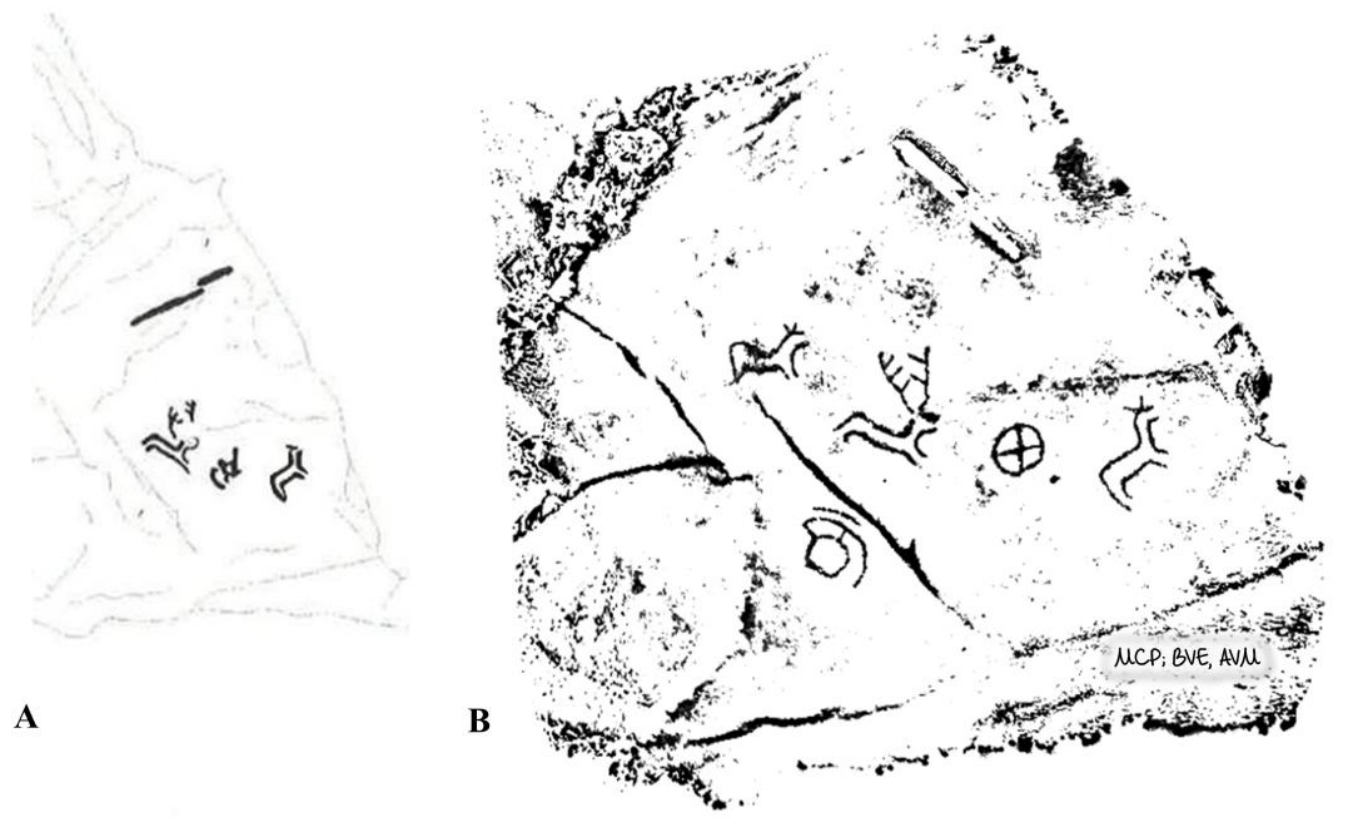

Figure 12. Outeiro dos Cogoludos II.6. A: Following Comendador Rey (2008a, b); B: Our proposal. 